Part of Journai of Research of the National Bureau of Standards, Volume 28, January 1942

\title{
SOIL-CORROSION STUDIES, 1939. COATINGS FOR THE PROTECTION OF METALS UNDERGROUND
}

\author{
By Kirk H. Logan
}

\section{ABSTRACT}

In this paper is reported the condition of specimens of metallic and nonmetallic coatings after exposure to soils for periods ranging from 2 to 16 years. Conclusions previously drawn relative to the protective value of zinc and lead coatings are generally confirmed by the latest inspections. A specially applied zinc coating prevented serious pitting in 16 soils over a 16 -year period, but a commercial coating of the same weight, exposed to more corrosive soils, did not prevent pitting entirely during the initial 2-year period. Lead corrodes sufficiently in many soils to render lead coatings unsatisfactory. Tin applied as a protective coating was of little benefit in reducing the corrosion of copper in soils. A 7-year-old vitreous enamel, two 7-year old hard-rubber coatings, and a 2-year-old baked synthetic resin coating have shown little or no evidence of failure.

\section{CONTENTS}

I. Introduction

II. Methods of testing 57

1. Metallic coatings _._.

2. Nonmetallic coatings___._. 59

III. Metallic coatings

1. Zinc $\ldots \ldots \ldots \ldots$

(a) Specimens exposed 16 years $\ldots \ldots \ldots \ldots \ldots \ldots$

(b) Specimens exposed 2 years $\ldots \ldots$

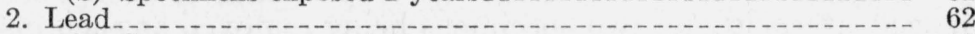

(a) Specimens exposed 16 years $\ldots \ldots \ldots \ldots \ldots \ldots$

(b) Specimens exposed 7 years

3. Tinned copper.

4. Parkway cable _._. 65

IV. Nonmetallic coatings

1. Bituminous _........ 66

2. Nonbituminous _... 68

(a) Specimens exposed 7 years

(b) Specimens exposed 2 years

V. Conclusions

\section{INTRODUCTION}

The primary purposes of the field tests of pipe coatings being conducted by the National Bureau of Standards are (1) to furnish information on the protective value of various metallic and nonmetallic coatings to pipe-line operators and others concerned with the storage, transportation, and distribution of fluids underground, and (2) to assist in the development of improved coatings by studying their performance under a variety of soil conditions. 
The selection of coatings for test has been largely in the hands of coating manufacturers, no attempt having been made to cover the field systematically. As the performance of coatings of a given type may vary, depending on details of manufacture, the results of the tests, particularly with respect to nonmetallic coatings, do not always justify generalizations regarding the different coatings as types. Nevertheless, the data obtained will be of value to those interested in the particular coatings tested and to those whose knowledge of coating materials enables them to make deductions concerning the possible results of modifications.

In considering the data to be presented, it should be remembered that service conditions are probably more severe than thoise under which the tests were made. Aside from the possibility of mproper application and injury to the coating during transportation and installation, the weight of pipe lines and their movement due to changes in temperature, and the stresses set up by shrinking and swelling of the soil with changes on moisture, etc., impose greater strains on coatings in service than on those applied to isolated sections of small pipe. Also, there is much less chance of a failure or defect occurring on a test specimen with an area of 0.67 square foot than, for example, on a pipe 20 feet in length and 8 inches in diameter, an area of 40 square feet. Although a small number of specimens of coated pipe or sheet may not constitute a representative sample, the performance of the specimens under a variety of environments affords some idea of the general usefulness of the coating in comparison with other coatings tested under the same conditions.

\section{METHODS OF TESTING}

\section{METALLIC COATINGS}

Specimens of metallic coatings applied to both sheet and pipe were exposed to soil corrosion at 47 test sites in 1923 and 1924. Other series of tests of coatings applied to pipe were installed in 1932 and 1937 at an additional group of 15 sites. The soil conditions at six sites were similar in all of the tests. Ten specimens of each coating were buried at each site, two specimens being removed at each inspection. Beginning in 1932 the specimens were protected from shock and abrasion in transit by means of standard caps screwed on the threaded ends of the coated pipe. The threaded pipe was $1 \frac{1}{2}$-inches in diameter and of such length that one linear foot of coating was exposed between the capped ends.

The depth of the deepest pits and the loss of weight of the pipes, together with observations of the surface condition, were taken as measures of the effectiveness of the coatings. In the present report, corrosion losses are reported as the total loss in weight over the period rather than as a rate of loss. In previous reports, the losses were reported as rates in order to make the data for specimens differing slightly in age more nearly comparable. However, past experience has shown that no advantage is gained by using rates of loss of weight as criteria for comparing the corrosion on different coatings or metals. Even for a uniform material, corrosion is not usually proportional to the time of exposure, the nature of the corrosion-time relation depending in part on the corroding medium. Pit depths are somewhat 
more indicative of the condition of a metal-coated specimen than is loss of weight, since the coating must be punctured before measurable pits can develop.

\section{NONMETALLIC COATINGS}

The methods of testing nonmetallic coatings have been altered somewhat since the first tests of coatings began. The coatings on which tests were started in 1924 were applied to steel pipe, 18 inches in length and $1 \frac{1}{2}$ inches in internal diameter, from which the mill scale had been removed by pickling. Five specimens of each coating were buried at each test site. One specimen was removed at intervals of 2 or more years and returned to the laboratory for examination. Ten specimens of the coatings buried in 1932 and later were exposed at each test site, and two specimens were removed every 2 years or at longer intervals. These coatings were applied by the manufacturer to pipe $1 \frac{11}{2}$ inches in internal diameter, 1 linear foot of coating being exposed for test. They were protected in handling by means of caps, as described in the previous section on metallic coatings. The specimens were inspected according to a definite system. The coating was then removed from one-half of the pipe and the depths of the deepest five pits were measured. Although the electrical resistance, or conductance, of coatings which might be classed as insulating materials has been used as a measure of the condition of the coating, this test was not employed in the present study. Conductance is not a satisfactory criterion for the condition of coatings that are not uniform in thickness nor for those which contain inhibiting chemicals or metallic or other conducting shields.

\section{METALLIC COATINGS}

\section{ZINC}

(a) SPECIMENS EXPOSED 16 YEARS

Specimens of galvanized sheet and pipe were buried originally for the purpose of determining the importance of factors such as the thickness of the coating, the kind of base metal, and the exposure conditions. A detailed report ${ }^{1}$ on the behavior of these and other coatings was prepared after the specimens had been exposed 10 years. The location of the test sites and data on the properties of the soils are given in this report. As specimens in many of the soils showed little or no corrosion after 10 years, it was decided to allow the specimens in the less corrosive soils to remain for a longer period. The condition of these specimens after 16 years is shown in table 1 .

Since there were fewer specimens and the corrosiveness of the soils was relatively slight, the differences in behavior indicated by the data are not as striking as those presented in the earlier report. However, the conclusions reached in that report with regard to the importance of coating thickness and the negligible effect of the kind of base metal are borne out by the present data. For example, the protection afforded by the coating of 2.82 ounces per square foot on open-hearth iron pipe was such that measurable pits developed on the specimens in only a few of the soils over a period of 16 years. Some zinc remained on many of the specimens at the end of the test.

\footnotetext{
${ }^{1}$ Kirk H. Logan and Scott P. Ewing, J. Research NBS 18, 361 (1936) RP982,
} 
$a=$ uniform corrosion.
$b=$ hole due to union of pits from both sides of sheet.

$b=$ hole due to union of pits from
$c=$ no coating left on specimen.

$\begin{aligned} c & =\text { no coating } \\ U & =\text { no pitting. }\end{aligned}$

$M=$ metal attack-pits less than 1 mil in depth.

$P=$ pits not greater than 6 mils in depth.

$+=$ specimen punctured.

\begin{tabular}{|c|c|c|c|c|c|c|c|c|c|c|c|}
\hline \multicolumn{2}{|r|}{ Soil } & \multicolumn{6}{|c|}{ Sheet ${ }^{3}$} & \multicolumn{4}{|c|}{ Pipe } \\
\hline \multirow{2}{*}{ No. } & \multirow{2}{*}{ Type } & \multicolumn{2}{|c|}{$\begin{array}{l}{ }^{3} 0.99 \mathrm{oz} / \mathrm{sq} \mathrm{ft} \text { on open- } \\
\text { hearth iron }\end{array}$} & \multicolumn{2}{|c|}{$\begin{array}{l}0.81 \mathrm{oz} / \mathrm{sq} \mathrm{ft} \text { on Bes- } \\
\text { semer steel }\end{array}$} & \multicolumn{2}{|c|}{$\begin{array}{c}1.07 \mathrm{oz} / \mathrm{sq} \mathrm{ft} \text { on copper- } \\
\text { bearing steel }\end{array}$} & \multicolumn{2}{|c|}{$\begin{array}{l}2.82 \mathrm{oz} / \mathrm{sq} \mathrm{ft} \text { on open- } \\
\text { hearth iron }{ }^{4}\end{array}$} & \multicolumn{2}{|c|}{$\begin{array}{l}\text { Uncoated Bessemer } \\
\text { steel } s\end{array}$} \\
\hline & & $\begin{array}{l}\text { Loss of } \\
\text { weight }\end{array}$ & $\begin{array}{l}\text { Penetra- } \\
\text { tion }\end{array}$ & $\begin{array}{l}\text { Loss of } \\
\text { weight }\end{array}$ & $\begin{array}{l}\text { Penetra- } \\
\text { tion }\end{array}$ & $\begin{array}{l}\text { Loss of } \\
\text { weight }\end{array}$ & $\begin{array}{l}\text { Penetra- } \\
\text { tio }\end{array}$ & $\begin{array}{l}\text { Loss of } \\
\text { weight }\end{array}$ & $\begin{array}{l}\text { Penetra- } \\
\text { tion }\end{array}$ & $\begin{array}{l}\text { Loss of } \\
\text { weight }\end{array}$ & $\begin{array}{l}\text { Penetra- } \\
\text { tion }\end{array}$ \\
\hline & Bell clay & $o z / f t_{1.52}^{2}$ & Mils $_{21}$ & $0 z / f t_{1.27}^{2}$ & $\begin{array}{ll}\text { Mils } & \\
& \\
& \end{array}$ & $0 z / f t^{2}$ & Mils $_{16}$ & $0 z / f t^{2}$ & Mils & $0 z / f t^{2}$ & Mils \\
\hline 5 & Dublin clay adobe................. & 1. 31 & $26(a, c)$ & 4. 26 & $28(a, c)$ & $\begin{array}{l}\text { 1. } 47 \\
3.49\end{array}$ & $20(a, c)$ & 3. 23 & $\stackrel{14(C)}{P}$ & 8.58 & $\begin{array}{l}58 \\
68\end{array}$ \\
\hline 6 & Everett gravelly sandy loam.- & 0.96 & $U$ & 0.91 & $P$ & 0.70 & & 0.37 & $P$ & 1. 88 & 23 \\
\hline 7 & Maddox silt loam & 5.19 & $54(b, c)$ & & & & & $\begin{array}{l}7.39 \\
1.64\end{array}$ & $11(c)$ & 5. 06 & 57 \\
\hline $\begin{array}{r}9 \\
12\end{array}$ & $\begin{array}{l}\text { Genesee silt loam } \\
\text { Hanford fine sandy loam }\end{array}$ & $\begin{array}{l}1.90 \\
0.89\end{array}$ & $\begin{array}{l}36 \\
M\end{array}$ & 1.81 & $\stackrel{37}{P}$ & $\begin{array}{l}1.77 \\
0.75\end{array}$ & $\stackrel{30}{P}$ & 61.64 & $0_{011}^{M}$ & $\begin{array}{l}5.10 \\
5.32\end{array}$ & $\begin{array}{l}74 \\
99\end{array}$ \\
\hline 17 & Keyport loam & 7.44 & $36(c)$ & 6.17 & $29(c)$ & 6.16 & $30(c)$ & $\begin{array}{l}1.09 \\
3.93\end{array}$ & $18(c)$ & 9.51 & 52 \\
\hline 24 & Merrimac gravelly sandy loam & 0.43 & $P$ & 0.27 & $P$ & 1.14 & $P$ & ${ }^{\circ} 0.32$ & ${ }^{6} P$ & 1. 56 & 42 \\
\hline 25 & $\begin{array}{l}\text { Miami clay loam } \\
\text { Miami silt loam }\end{array}$ & & & & & & & 1.76 & $P$ & 2.73 & \\
\hline 26 & Miami silt loam & 1.37 & 22 & 1.15 & 16 & 1.3 & 17 & 1. 25 & $P$ & 4.77 & \\
\hline 27 & Miller clay & 2.45 & 12 & 2.41 & 10 & 1.88 & 12 & 2. & $D$ & 8. & \\
\hline 31 & Norfolk sand & 0.89 & $M$ & 0.46 & $P$ & 0.72 & $P$ & 0.46 & $P$ & 4. & \\
\hline 36 & Ruston sandy loam & 1.19 & $P$ & .90 & 12 & 1.10 & $P$ & .76 & $P$ & 2.58 & 7 \\
\hline 38 & Sassafras gravelly sandy loam & 0.56 & $M$ & .49 & $P$ & 0.54 & $P$ & .42 & $P$ & 2.81 & \\
\hline $\begin{array}{l}41 \\
47\end{array}$ & $\begin{array}{l}\text { Summit silt loam } \\
\text { Unidentified silt loam }\end{array}$ & 1.54 & 58 & 1.41 & $62+$ & 1. 66 & 28 & 190 & & 7. 03 & 112 \\
\hline & Unidentified silt & & & & & & & & & & \\
\hline
\end{tabular}

1 Values for single specimens unless otherwise indicated.

Area approximately 110 inches of exposed coating.

3 Weight of coating on one side. This is half the nominal weight of the coating on sheets.

Two-inch pipe, 17 inches long.

6 3-inch pipe, 10 inches long. This pipe was buried in 1922 


\section{(b) SPECIMENS EXPOSED 2 YEARS}

The marked protective value of heavy zinc coatings, which was indicated by the inspection of the 10-year-old specimens, led to the burial in 1937 of steel specimens with a coating having a weight of 3.08 ounces per square foot at the 15 sites previously mentioned. The condition of these specimens after 2 years is shown in table 2 . Unless otherwise stated, the values shown in this and in succeeding tables are averages of measurements made on two specimens.

TABLE 2.-Loss of weight and depth of maximum penetration of galvanized and black iron pipe exposed 2 years

\begin{tabular}{|c|c|c|c|c|c|c|}
\hline \multicolumn{2}{|r|}{ Soil } & \multicolumn{2}{|c|}{$\begin{array}{l}\text { Galvanized pipe } 3.08 \\
\text { oz/ft }\end{array}$} & \multicolumn{2}{|c|}{ Black iron pipe } & \multirow{2}{*}{$\begin{array}{l}\text { Condition } \\
\text { of coating } 1\end{array}$} \\
\hline No. & Type & $\begin{array}{l}\text { Loss of } \\
\text { weight }\end{array}$ & $\begin{array}{l}\text { Penetra- } \\
\text { tion }\end{array}$ & $\begin{array}{l}\text { Loss of } \\
\text { weight }\end{array}$ & $\begin{array}{l}\text { Penetra- } \\
\text { tion }\end{array}$ & \\
\hline & Acadiaclav & $0 z / f t^{2}$ & Mils & $02 / f t^{2}$ & Mils $_{52}$ & \\
\hline $\begin{array}{l}51 \\
55\end{array}$ & $\begin{array}{l}\text { Acadia clay } \\
\text { Cecil clay loam }\end{array}$ & $\begin{array}{l}3.32 \\
0.26\end{array}$ & $\begin{array}{l}6 \\
9\end{array}$ & $\begin{array}{l}7.48 \\
1.77\end{array}$ & $\begin{array}{l}52 \\
42\end{array}$ & 3 \\
\hline 55 & Hagerstown loam. & .34 & 5 & 1.80 & 33 & 1 \\
\hline 56 & Lake Charles clay & 3. 68 & 5 & 13.78 & 77 & 3 \\
\hline 58 & Muck & 4. 29 & 13 & 5.08 & 29 & 3 \\
\hline $59 \mathrm{~b}$ & Houghton muck. & 1. 20 & 8 & 1. 47 & 12 & 2 \\
\hline 60 & Rifle peat & 4. 27 & 10 & 4.03 & 15 & 3 \\
\hline 61 & Sharkey clay & 0.64 & 6 & 2. 24 & 40 & 1 \\
\hline 62 & Susquehanna clay.................. & 1.03 & 12 & 3.21 & 40 & 1 \\
\hline 63 & 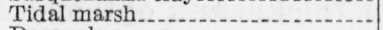 & 1. 16 & $2 P$ & 2. 74 & 24 & 1 \\
\hline 64 & Docas clay & 3. 16 & 8 & 8.72 & 80 & 3 \\
\hline 65 & Chino silt loam & 1.09 & $P$ & 4. 30 & 50 & 2 \\
\hline 66 & Mohave sandy loam & 1.59 & 6 & 9.23 & $3145+$ & 1 \\
\hline 67 & Cinders & 6.74 & 62 & 40.47 & $145+$ & 3 \\
\hline 70 & Merced silt loam & 2.08 & 8 & 4.93 & 50 & 1 \\
\hline
\end{tabular}

${ }^{1} 1=$ coating on more than 50 percent of surface.

$2=$ coating on less than 50 percent of surface.

$3=$ little or no coating remaining.

$2 P=$ no pits greater than 6 mils.

$3+=$ one or both specimens punctured.

As will be seen in table 2, pits developed in the specimens of galvanized pipe at nearly every test site in 2 years. This result is inconsistent with the data of previously described tests, in which a coating of 2.82 ounces per square foot prevented pitting of the base metal in all but one of 47 soils over a 10-year period. Although certain of the soils in the second series of tests proved to be more corrosive than any in the original series, it is also true that six soil conditions were duplicated in the two series of tests, as previously stated.

This difference in behavior of specimens having coatings of nominally the same thickness is possibly to be ascribed to greater uniformity of the coating in the earlier tests for which the specimens were recoated individually, that is, a second coat was applied after the pipe had been cut into the desired lengths. This procedure might favor a relatively greater degree of uniformity of coating than is obtained by the usual hot-dip process. The impracticability of securing a perfectly uniform coating by the hot-dip process as used commercially has been previously noted. ${ }^{2} 3$

Pits developing in steel protected by a thick, uniform coating would not be expected to spread and deepen at an appreciable rate. The high cathodic current density on the exposed areas of steel would

${ }^{2}$ H. S. Rawdon, Protective Metallic Coatings (The Chemical Catalog Co., New York, N. Y., 1928).

${ }^{3}$ E. C. Groesbeck and W. A. Tucker, BS J. Research 1, 255 (1928) RP10. 
reduce the galvanic current, and consequently the rate of removal of zinc in the vicinity of the exposed area would be very low. However, if the coating were not uniform in thickness, pits developing in areas where the zinc coating was thin would be expected to spread and deepen. With the removal of the thin layer of zinc surrounding the pit, the exposed cathodic area would become more and more difficult to protect cathodically, and as a consequence the galvanic current and rate of removal of zinc would be proportionately greater. In fact, the corrosion of zinc might even be accelerated because of the large cathodic area provided by extensive removal of zinc.

While the difference in behavior of the two groups of specimens having nominally thick coatings cannot definitely be attributed to differences in uniformity, this factor must be given due consideration before drawing final conclusions relative to the protective value of zinc coatings in soils.

\section{LEAD}

\section{(a) SPECIMENS EXPOSED 16 YEARS}

All the specimens of lead-coated pipe which were buried in 47 soils in 1923 and 1924 were removed from the more corrosive soils in 1934 , but one set of specimens was allowed to remain in the less corrosive soils until 1939. The condition of these latter specimens is shown in table 3. The average thickness of the lead coating was 1.05 mils. The maximum and minimum thicknesses obtained from 12 measurements were 2.50 and 0.30 mils, respectively.

The data of table 3 confirm the conclusions reached in the previous report (see footnote 1), namely, that lead coatings of the thickness applied do not afford adequate protection. As was observed in the earlier inspection, the coated specimens in many of the soils developed deeper pits than did the specimens of unprotected steel.

TABLE 3.-Loss of weight and depth of maximum penetration of 11/2-inch lead-coated pipe and Bessemer steel pipe exposed 16 years ${ }^{1}$

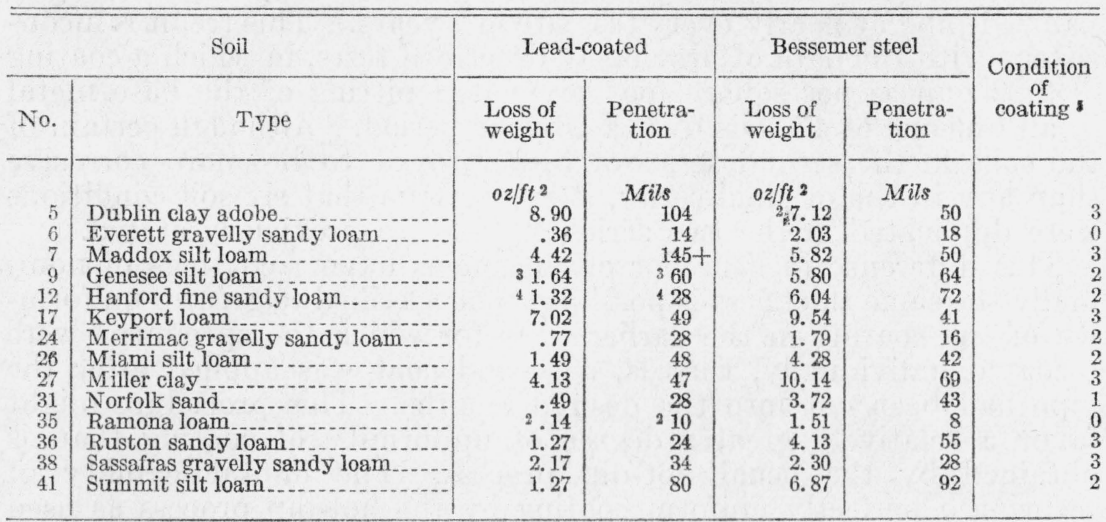

1 Lead-coated pipe buried in 1923-24.

Bessemer steel pipe buried in 1922

2 Data on one specimen only.

3 Average of 3 specimens.

4 Average of 4 specimens.

$50=$ coating over entire specimen.

$1=$ coating on more than 50 percent of surface.

$2=$ coating on less than 50 percent of surface.

$3=$ little or no coating left. 


\section{(b)ISPECIMENS EXPOSED 7 YEARS}

Improvements in the process of coating pipe with lead have been made since the first sets of specimens were buried in 1925 . Accordingly, specimens of lead-coated pipe 14 inches long and 11/2 inches in diameter and coated by the newer process were buried at 15 test sites in 1932. The average thickness of the coating was 1.44 mils, and the maximum and minimum thicknesses of a group of 12 measurements were 2.97 and 0.50 mils, respectively. The corrosion data are shown in table 4 . In very few soils could the protection provided by the lead coating be considered adequate.

Since lead, unlike zinc, is cathodic to iron and steel, protection of the underlying metal is accomplished chiefly by isolating the base metal from the environment. The life of the coating would then be expected to be determined largely by the corrodibility of lead under the conditions of exposure. Unless the rate of a verage penetration of lead is small relative to the thickness of the coating, the life of the coating would obviously be short. Furthermore, if the corrosion of lead in soils takes the form of localized attack, or pitting, the potential difference between lead and the exposed steel would cause accelerated attack except under those conditions in which the steel might be polarized anodically. It is, therefore, of interest to consider the average and maximum penetrations of lead in the various soils. In table 5 are shown values for the average and maximum penetrations of specimens of various kinds of lead which had been exposed to the same soils for 2 years.

TABLE 4.-Loss of weight and depth of maximum penetration of lead-coated and steel pipe exposed 7 years

\begin{tabular}{|c|c|c|c|c|c|c|}
\hline \multicolumn{2}{|r|}{ Soil } & \multicolumn{2}{|c|}{ Lead-coated } & \multicolumn{2}{|c|}{ Low-carbon tube } & \multirow{2}{*}{$\begin{array}{c}\text { Condition } \\
\text { of } \\
\text { coating }{ }^{1}\end{array}$} \\
\hline No. & Туре & $\begin{array}{l}\text { Loss of } \\
\text { weight }\end{array}$ & $\begin{array}{c}\text { Penetra- } \\
\text { tion }\end{array}$ & $\begin{array}{l}\text { Loss of } \\
\text { weight }\end{array}$ & $\begin{array}{l}\text { Penetra- } \\
\text { tion }\end{array}$ & \\
\hline $\begin{array}{l}51 \\
53 \\
55 \\
56 \\
58 \\
59 \mathrm{a} \\
60 \\
61 \\
62 \\
63 \\
64 \\
65 \\
66 \\
67\end{array}$ & $\begin{array}{l}\text { Acadia clay } \\
\text { Cecil clay loam } \\
\text { Hagerstown loam } \\
\text { Lake Charles clay } \\
\text { Muck } \\
\text { Carlisle muck } \\
\text { Rifle peat } \\
\text { Sharkey clay. } \\
\text { Susquehanna clay } \\
\text { Tidal marsh } \\
\text { Docas clay } \\
\text { Alkali soil. } \\
\text { Mohave sandy loam } \\
\text { Cinder }\end{array}$ & $\begin{array}{r}\text { oz/ft }{ }^{2} \\
9.23 \\
1.65 \\
1.10 \\
10.18 \\
11.76 \\
.35 \\
2.44 \\
3.32 \\
2.11 \\
.46 \\
1.63 \\
3.80 \\
4.41 \\
4 D\end{array}$ & $\begin{array}{c}\text { Mils } \\
104 \\
44 \\
44 \\
2140+ \\
90 \\
7 \\
60 \\
70 \\
47 \\
3 P \\
56 \\
53 \\
61 \\
2145+\end{array}$ & $\begin{array}{r}\text { oz/ft' } \\
11.50 \\
4.18 \\
3.21 \\
20.97 \\
14.08 \\
3.00 \\
7.63 \\
5.65 \\
5.32 \\
7.07 \\
35.58 \\
13.73 \\
14.34 \\
23.54\end{array}$ & $\begin{array}{c}\text { Mils } \\
2135+ \\
54 \\
57 \\
2125+ \\
110 \\
30 \\
17 \\
63 \\
71 \\
70 \\
2154+ \\
83 \\
2154+ \\
2127+\end{array}$ & 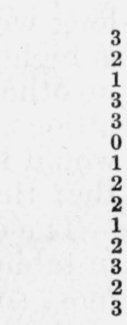 \\
\hline
\end{tabular}

$10=$ coating over entire specimen.

$1=$ coating on more than 50 percent of surface.

$2=$ coating on less than 50 percent of surface.

$3=$ little or no coating left.

$+=0$ e or both specimens punctured.

$P=$ no pits greater than 6 mils.

i $D=$ both specimens destroyed. 
TABLE 5.-Average and maximum penetrations of lead pipe exposed 2 years

\begin{tabular}{|c|c|c|c|c|c|c|}
\hline \multirow[b]{2}{*}{ Soil No. } & \multicolumn{2}{|c|}{ Chemical lead 1} & \multicolumn{2}{|c|}{ Tellurium lead 2} & \multicolumn{2}{|c|}{ Antimonial lead ${ }^{3}$} \\
\hline & $\begin{array}{l}\text { Average } \\
\text { penetra- } \\
\text { tion }\end{array}$ & $\begin{array}{c}\text { Maximum } \\
\text { penetra- } \\
\text { tion }\end{array}$ & $\begin{array}{l}\text { Average } \\
\text { penetra- } \\
\text { tion }\end{array}$ & $\begin{array}{l}\text { Maximum } \\
\text { penetra- } \\
\text { tion }\end{array}$ & $\begin{array}{l}\text { Average } \\
\text { penetra- } \\
\text { tion }\end{array}$ & $\begin{array}{c}\text { Maximum } \\
\text { penetra- } \\
\text { tion }\end{array}$ \\
\hline $\begin{array}{l}51 \\
53 \\
55 \\
56 \\
58 \\
59 \mathrm{~b} \\
60 \\
61 \\
62 \\
63 \\
64 \\
65 \\
66 \\
67 \\
70\end{array}$ & $\begin{array}{r}\text { Mils } \\
0.68 \\
.24 \\
.41 \\
.23 \\
1.70 \\
0.39 \\
.20 \\
4.59 \\
0.33 \\
.06 \\
.22 \\
.15 \\
.11 \\
4.00 \\
0.04\end{array}$ & $\begin{array}{c}\text { Mils } \\
40 \\
24 \\
24 \\
38 \\
62 \\
28 \\
21 \\
41 \\
38 \\
15 \\
32 \\
46 \\
44 \\
84 \\
54\end{array}$ & $\begin{array}{c}\text { Mils } \\
1.32 \\
0.27 \\
.37 \\
.41 \\
1.83 \\
0.25 \\
.16 \\
4.32 \\
0.39 \\
.061 \\
.27 \\
.19 \\
.27 \\
3.65 \\
0.10\end{array}$ & $\begin{array}{c}\text { Mils } \\
54 \\
16 \\
32 \\
68 \\
55 \\
18 \\
33 \\
35 \\
28 \\
15 \\
38 \\
41 \\
35 \\
74 \\
22\end{array}$ & $\begin{array}{r}\text { Mils } \\
1.14 \\
0.27 \\
.21 \\
.34 \\
1.58 \\
0.22 \\
.11 \\
4.02 \\
0.29 \\
.04 \\
.13 \\
.19 \\
.07 \\
3.42 \\
0.11\end{array}$ & $\begin{array}{c}\text { Mils } \\
56 \\
12 \\
28 \\
42 \\
52 \\
10 \\
10 \\
44 \\
20 \\
8 \\
25 \\
8 \\
19 \\
58 \\
16\end{array}$ \\
\hline
\end{tabular}

$1 \mathrm{Cu}, 0.056$ percent; $\mathrm{Sb}, 0.0011$ percent; $\mathrm{Bi}, 0.002$ percent.

${ }^{2} \mathrm{Cu}, 0.082$ percent; $\mathrm{Sb}, 0.0011$ percent; Te, 0.043 percent.

${ }^{3} \mathrm{Cu}, 0.036$ percent; $\mathrm{Bi}, 0.016$ percent; $\mathrm{Sb}, 5.31$ percent.

4 Individual specimens differ from the average by more than 50 percent.

The average penetration of the different varieties of lead in several of the soils approached, and in certain soils exceeded, the minimum thickness of the lead coating, namely, $0.50 \mathrm{mil}$. In fact, in four soils, Nos. $51,58,61$, and 67 , the average penetration of lead in 2 years did not differ greatly from the average thickness of the coating, 1.44 mils. Apart from considerations of over-all corrosion, the relatively high rate of pitting of the lead specimens in nearly all of the soils would undoubtedly cause perforation of a coating of any reasonable thickness within 2 years.

\section{TINNED COPPER}

Specimens of tinned copper tubes 1 inch in diameter and 14 inches long were exposed to corrosion in 15 soils in 1937. Although copper is highly resistant to corrosion in many soils, it corrodes appreciably in others. As tin is probably anodic to copper under all soil conditions, the corrosion of tin applied to copper as a metallic coating would be expected to protect copper cathodically in the same manner that the corrosion of zinc protects steel in galvanized materials.

The condition of the tinned copper specimens after 2 years is shown in table 6. As will be seen, the loss in weight of the tinned copper in most soils was less than that for unprotected copper, but the depths of the maximum pits on the coated specimens were usually greater.

A probable explanation of the deeper pits on the specimens of tinned copper is suggested by the work of Merica, ${ }^{4}$ who found that copper was anodic to one of the copper-tin alloys formed in the process of tinning.

\footnotetext{
${ }_{4}$ P. D. Merica, Tech. Pap. BS 9, (1917) T90.
} 
TABLE 6.-Loss of weight and depth of maximum penetration of tinned copper tubes and copper pipe exposed 2 years

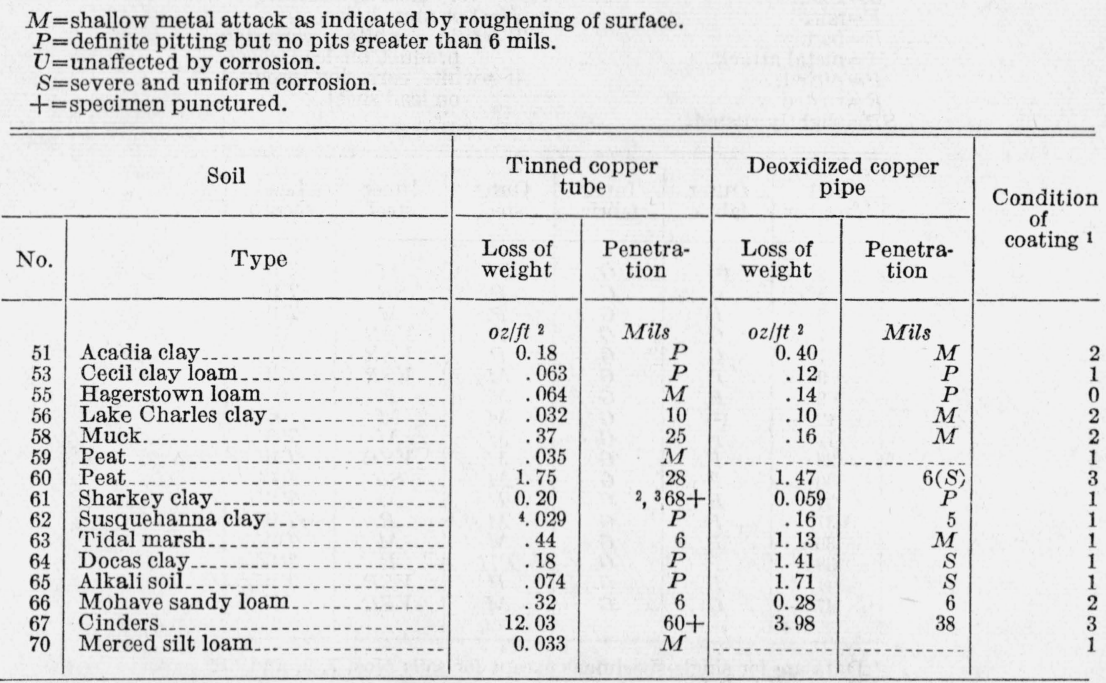

$10=$ coating present over entire specimen.

$1=$ coating on more than 50 percent of surface.

$2=$ coating on less than 50 percent of surface.

$3=$ little or no coating left.

2 Individual measurements differ from the average by more than 50 percent.

3 Hole in cap of one specimen.

4 One specimen only.

\section{PARKWAY CABLE}

The parkway cable which was tested had a rubber-covered copper wire within a lead sheath. The sheath was wrapped with jute, and on this wrapper two spiral ribbons of zinc-coated steel were wound in opposite directions. These spirals were followed by an outer wrapper of bitumen-impregnated jute. Although most cables are laid in some form of conduit, this cable is usually laid directly in the soil.

Specimens were buried in 47 soils in 1923 and 1924. The last of these were removed from the corrosive soils in 1934 and their condition has been reported (see foot note 1). Table 7 shows the condition of the several protective layers. It will be noted that in all of the mildly corrosive soils the copper was completely protected throughout the 16 years of the test and would probably remain serviceable for many more years. 
TABLE 7.-Condition of parkway cable ${ }^{1}$ exposed 16 years

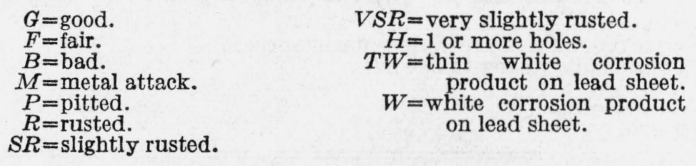

\begin{tabular}{|c|c|c|c|c|c|}
\hline $\begin{array}{c}\text { Soil } \\
\text { Number }\end{array}$ & $\begin{array}{l}\text { Outer } \\
\text { fabric }\end{array}$ & $\begin{array}{l}\text { Inner } \\
\text { fabric }\end{array}$ & $\begin{array}{l}\text { Outer } \\
\text { steel }\end{array}$ & $\begin{array}{l}\text { Inner } \\
\text { steel }\end{array}$ & $\begin{array}{l}\text { Lead } \\
\text { sheath }\end{array}$ \\
\hline $\begin{array}{r}2 \\
5 \\
6 \\
7 \\
37 \\
9 \\
39 \\
12 \\
17 \\
26 \\
30 \\
31 \\
331 \\
36 \\
38 \\
41 \\
47\end{array}$ & $\begin{array}{c}(2) \\
G \\
F \\
G \\
G \\
G \\
B \\
B \\
(2) \\
F \\
F \\
F \\
F \\
B \\
F \\
F \\
F \\
B \\
G\end{array}$ & $\begin{array}{l}G \\
G \\
G \\
G \\
G \\
G \\
G \\
G \\
G \\
G \\
G \\
G \\
G \\
G \\
G \\
G \\
G \\
G\end{array}$ & $\begin{array}{c}M \\
P \\
P \\
P \\
P \\
M \\
M \\
M \\
M \\
M \\
M \\
P \\
M \\
M \\
P H \\
P \\
M\end{array}$ & $\begin{array}{c}M \\
S R \\
M \\
V S R \\
V S R \\
V S R \\
R \\
M \\
M \\
V S R \\
V R \\
M \\
M \\
R \\
M \\
R \\
V S R \\
V S R\end{array}$ & $\begin{array}{c}T W \\
T W \\
T W \\
W \\
P \\
T W \\
W \\
W \\
T W \\
T W \\
T W \\
T W \\
T W \\
T W \\
T W \\
T W \\
W\end{array}$ \\
\hline
\end{tabular}

1 Data are for single specimens except for soils Nos. 7, 9, and 31 . 2 Removed in field.

3 Second sample.

\section{NONMETALLIC COATINGS}

\section{BITUMINOUS}

Three types of bituminous coatings, all of the hot-dipped variety, were buried at 47 test sites in 1924-namely, No. 4, asphalt coating; No. 7, a coal-tar pitch coating; and No. 10, an asphalt coating reinforced with cotton fabric. The last inspection of these coatings was made in 1934, when the last sets were removed from the more corrosive soils. In the report ${ }^{5}$ in which the condition of these coatings was described will be found data on the behavior of many types of coatings. The appearance and general condition of the coatings removed in 1939 from 16 sites were practically unchanged since the last inspection.

The coal-tar pitch dip coating, designated as No. 7, had a freecarbon content of 17 percent and a ring-and-ball softening point of $195^{\circ} \mathrm{F}$. It was applied by twice dipping the pipe vertically into the coating bath, which was held at $250^{\circ}$ to $260^{\circ} \mathrm{F}$. The thickness of the coating was approximately 0.007 inch. Numerous rust spots appeared on the surface of the coating at nearly all test sites. The coating appeared to be brittle, and in many cases part of it could be brushed from the pipe.

The asphalt coating (No. 4) was prepared from the residuum from Mexican petroleum. The penetration of this material at $77^{\circ} \mathrm{F}$, $100 \mathrm{~g}, 5 \mathrm{sec}$, was 20 . The softening point (ring-and-ball method) was $185^{\circ} \mathrm{F}$. The pipe was dipped twice in the bituminous material, which was held at approximately $350^{\circ} \mathrm{F}$. The thickness of the coating varied between 0.008 and 0.016 inch. The appearance of this coating when removed from the soil was similar to that of coating No. 7 .

6 Kirk H. Logan, J. Research NBS 19, 695 (1937) RP1058. 
Neither coating was thick enough to prevent moisture reaching the pipe or to afford adequate protection, although the pits on the pipes having these coatings were not so deep (table 8) as on uncoated pipes. Such coatings are not now in general use on steel pipe, but a coal-tar dipped coating is commonly applied to cast-iron water pipe.

The reinforced asphalt coating, No. 10, consisted of a mixture of gilsonite and midcontinent asphalt reinforced by a woven cotton fabric applied in a lathe-type machine. The fabric passed through a tank of molten asphalt as it was wound spirally on the pipe. The thickness of the coating was approximately 0.08 inch. In a few of the soils this coating was apparently unchanged after 15 years' exposure. In most of the soils, however, the coating developed irregular cracks, the fabric rotted, and the bitumen appeared to have lost some of its oily constituents, so that it was friable. Rusting occurred on all of the pipes to which this coating was applied, but in 14 of the 16 soils the maximum depth of pitting was less than 25 mils.

Table 8 shows the maximum pit depths beneath the hot-dipped coatings in 16 soils. The last column shows the maximum pit depths on uncoated pipe, having a slightly greater area, after 17 years' exposure. This column shows clearly that the soils were not very corrosive, since in only one of them did the maximum pit depth exceed 100 mils. Two coated specimens having wall thicknesses of 0.145 inch exposed to Dublin clay were punctured, although the maximum pit depth on the uncoated pipe in this soil was only 50 mils.

TABLE 8.-Maximum depth of penetration ${ }^{1}$ on bitumen-coated and bare pipe exposed 15 years

\begin{tabular}{|c|c|c|c|c|c|}
\hline \multicolumn{2}{|r|}{ Soil } & \multirow{2}{*}{$\begin{array}{l}\text { Coal-tar } \\
\text { pitch } \\
\text { (No. 7) }\end{array}$} & \multirow{2}{*}{$\begin{array}{l}\text { Asphalt } \\
\text { (No.4) }\end{array}$} & \multirow{2}{*}{$\begin{array}{l}\text { Asphalt, } \\
\text { reinforced } \\
\text { (No. 10) }\end{array}$} & \multirow{2}{*}{$\begin{array}{c}\text { Bare } \\
\text { steel }^{2}\end{array}$} \\
\hline No. & Type & & & & \\
\hline & & Mils & Mils & Mils & Mils \\
\hline $\begin{array}{l}2 \\
5\end{array}$ & Bell clay & $\begin{array}{c}422 \\
3145+\end{array}$ & 35 & $\begin{array}{l}122 \\
3145+\end{array}$ & $\begin{array}{l}70 \\
50\end{array}$ \\
\hline $\begin{array}{l}5 \\
6\end{array}$ & Everett gravelly sandy loam & $\begin{array}{c}145+ \\
15\end{array}$ & $\begin{array}{l}30 \\
14\end{array}$ & 15 & 21 \\
\hline 7 & Maddox silt loam & & & 422 & 68 \\
\hline 9 & Genesee silt loam & 31 & 13 & 414 & 76 \\
\hline 12 & Hanford fine sandy loam. & 12 & 19 & 20 & 81 \\
\hline 17 & Keyport loam & 430 & 428 & 011 & 42 \\
\hline 24 & Merrimac gravelly sandy loam & 20 & 13 & 620 & 33 \\
\hline 26 & Miami silt loam & 38 & 17 & 11 & 44 \\
\hline 27 & Miller clay ....................... & $\ldots$ & & 27 & 76 \\
\hline 31 & Norfolk sand.................. & 418 & & 30 & 52 \\
\hline 35 & Ramona loam & 20 & 10 & 14 & 18 \\
\hline 36 & Ruston sandy loam & 27 & 0 & 83 & 62 \\
\hline 38 & Sassafras gravelly sandy loam & 15 & 24 & 19 & 47 \\
\hline 41 & Summit silt loam & 430 & & 413 & 105 \\
\hline 47 & Unidentified silt loam.. & 106 & 10 & 415 & 60 \\
\hline
\end{tabular}

1 Data for single specimen unless otherwise noted.

2 Exposed 17 years.

3 Pipe punctured.

4 Average of the maximum pits on 2 specimens.

- Average of the maximum pits on 3 specimens.

- Average of the maximum pits on 5 specimens. 


\section{NONBITUMINOUS}

\section{(a) SPECIMENS EXPOSED 7 YEARS}

The only information available descriptive of the coatings buried in 1932 was furnished by the manufacturers and is given below.

Coating B.-A synthetic rubber, stated to be an olefin polysulfide reaction product, was exposed in the form of sheets 10 by 5 by $1 / 4$ inches. Subsequently, a process was developed which permitted application of this material to pipes. Specimens coated by this process were exposed in 1939 and inspected in 1941. The condition of these coatings will be described in a later report.

Coating $C$.- Two coats of vitreous enamel, one of which was acidresisting. Thickness, 14 mils.

Coating $D$.-First coat, 23-percent solution of a rubber derivative in xylene; second and third coats, 30-percent solution of the rubber derivative in xylene; fourth coat, 20-percent solution of the rubber derivative in a mixture of turpentine and mineral spirits. Five percent of the solids was carbon black. Thickness, 10 mils.

Coating E.-Two applications of paint which differed in color. Neither the kind of pigment nor the kind of vehicle was specified. Thickness, 5 mils.

Coating F.-A semiplastic compound, which was applied cold with a brush, consisting of $4 \frac{1}{2}$ parts of treated cashew-nutshell oil, 3 parts of asbestos fiber, and $3 \frac{1}{2}$ parts of mineral turpentine substitute. Thickness, 6 mils.

Coating G.-A hard-rubber compound, containing rubber, sulfur, and an accelerator, cured to a bone-hard condition. Thickness, 90 mils.

Coating H.-A highly loaded hard-rubber stock which contained 30 percent of magnesium carbonate and approximately 15 percent of "white substitute." Thickness, 100 mils.

Coating J.-A synthetic resin varnish baked at $425^{\circ} \mathrm{F}$ for 30 minutes.

Coating K.-A paint containing highly chlorinated rubber, dissolved in a suitable solvent, to which may have been added drying oils, pigments, quartz meal, or carborundum. This coating was applied in Germany to pipe 1 inch in outside diameter. Thickness, 6 mils.

Coating W.-An experimental coating prepared as follows: The pipe was primed with a china-wood oil varnish containing zinc chromate and basic lead chromate and baked at $200^{\circ} \mathrm{F}$ for $\frac{1}{2}$ hour. A top coat of dehydrated china-wood oil, containing powdered mica and a catalyst was molded on the pipe and heated to $200^{\circ} \mathrm{F}$ for 3 hours. Thickness, 170 mils.

The condition of the specimens after exposure to the soil for 7 years is shown in table 9 . 
TABLE 9.-Condition of miscellaneous nonmetallic coatings after exposure for 7 years

$E=$ ends corroded. $G=$ ends rusted. $H=$ pipe punctured $=145+$ mils. $M=$ metal attack, pipe roughened by corrosion. $R=$ rusted. $P=$ definite pitting, but no pits greater than 6 mils. $U=$ no corrosion. by corrosion, $R=$ rusted. $P=d e$
$+=$ pipe punctured after 5 years.

[Figures indicate depths of maximum pits in mils]

\begin{tabular}{|c|c|c|c|c|c|c|c|c|c|c|c|c|}
\hline \multicolumn{2}{|c|}{ Soil } & \multirow[b]{2}{*}{ 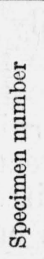 } & \multirow[b]{2}{*}{ 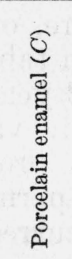 } & \multirow[b]{2}{*}{ 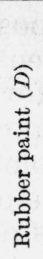 } & \multirow[b]{2}{*}{ 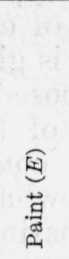 } & \multirow{2}{*}{ 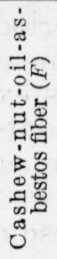 } & \multirow[b]{2}{*}{ 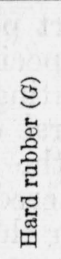 } & \multirow{2}{*}{ 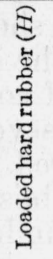 } & \multirow[b]{2}{*}{ 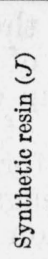 } & \multirow[b]{2}{*}{ 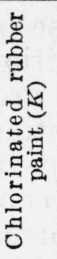 } & \multirow[b]{2}{*}{ 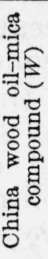 } & \multirow{2}{*}{ 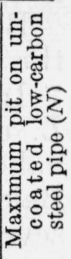 } \\
\hline$\dot{0}$ & Type & & & & & & & & & & & \\
\hline 51 & Acadia clay & 1 & $U E$ & 30 & 4 & $R$ & & & & & $M$ & 116 \\
\hline 53 & Cecil clay los & $\begin{array}{l}2 \\
1\end{array}$ & $\begin{array}{c}55(E) \\
U\end{array}$ & $\begin{array}{l}90 \\
M\end{array}$ & $\stackrel{82}{P}$ & $R$ & & & $R$ & & $\begin{array}{l}R \\
M\end{array}$ & $\begin{array}{l}\mathrm{H}+ \\
62\end{array}$ \\
\hline 55 & Hagerstown & $\begin{array}{l}2 \\
1\end{array}$ & $\begin{array}{l}U \\
M\end{array}$ & $\begin{array}{l}R \\
M\end{array}$ & $\begin{array}{l}15 \\
M\end{array}$ & $\begin{array}{l}R \\
R\end{array}$ & & & $R$ & & $\begin{array}{l}17 \\
R\end{array}$ & $\begin{array}{l}46 \\
52\end{array}$ \\
\hline & & 2 & $R$ & $M$ & $M$ & $R$ & & & & & $R$ & 62 \\
\hline 56 & Lake Charles clay & 1 & $E$ & 27 & $H$ & $M$ & - & . & & $R$ & $R$ & 96 \\
\hline 58 & Muck & 1 & $41(E)$ & 60 & $H$ & 60 & . & - & & & $\stackrel{M}{R}$ & $\begin{array}{r}11 \\
139\end{array}$ \\
\hline 59 & Pea & $\begin{array}{l}2 \\
1\end{array}$ & ${ }^{52(E)}$ & $\begin{array}{l}66 \\
14\end{array}$ & $\begin{array}{l}63 \\
15\end{array}$ & $\stackrel{46}{U}$ & $U G$ & $U$ & & & $\begin{array}{l}58 \\
R\end{array}$ & $\begin{array}{l}79 \\
38\end{array}$ \\
\hline & & 2 & & & 14 & $U$ & & $U$ & & & $\begin{array}{l}R \\
R\end{array}$ & $\begin{array}{l}38 \\
21\end{array}$ \\
\hline 60 & ..... do _ & 1 & $U E$ & 19 & 17 & $M$ & $U$ & $U$ & & & $R$ & 10 \\
\hline & & 2 & $U E$ & 42 & 23 & $R$ & $U G$ & $U$ & & & $R$ & 23 \\
\hline 61 & & $\begin{array}{l}1 \\
2\end{array}$ & $U E$ & $\begin{array}{l}R \\
R\end{array}$ & $\begin{array}{l}15 \\
25\end{array}$ & $\stackrel{R}{R}$ & 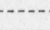 & - & & & $\begin{array}{l}R \\
U\end{array}$ & $\begin{array}{l}76 \\
50\end{array}$ \\
\hline 62 & Susquehanna clay - & 1 & $R$ & $R$ & 24 & $R$ & -. & ... & - & & $M$ & 83 \\
\hline 63 & Tidal & $\begin{array}{l}2 \\
1\end{array}$ & $\stackrel{U}{U E}$ & 21 & $\begin{array}{l}18 \\
15\end{array}$ & 70 & & $m$ & & & $\begin{array}{l}M \\
M\end{array}$ & $\begin{array}{l}58 \\
78\end{array}$ \\
\hline & & 2 & $U$ & $\bar{M}$ & 2 & $\Delta$ & & & & & $M$ & 61 \\
\hline 64 & Docas clay & 1 & $U$ & 45 & $H$ & $M$ & $U G$ & $U$ & 80 & 32 & $R$ & $H+$ \\
\hline 65 & A & 1 & $U$ & 20 & $H$ & $\begin{array}{l}20 \\
10\end{array}$ & $U$ & $U E$ & 50 & & $\stackrel{M}{R}$ & $\begin{array}{l}H- \\
90\end{array}$ \\
\hline & & 2 & $M$ & & & & & & & & $R$ & \\
\hline 66 & Mohave sandy loam _... & 1 & $U E$ & 19 & 100 & $M$ & $U$ & $U G$ & . & ... & $R$ & $H+$ \\
\hline 67 & Cinders... & $\begin{array}{l}2 \\
1\end{array}$ & $\begin{array}{l}U E \\
U E\end{array}$ & $\begin{array}{l}30 \\
M\end{array}$ & $\begin{array}{l}70 \\
63\end{array}$ & $\begin{array}{l}P \\
21\end{array}$ & $U C$ & $\begin{array}{l}U G \\
U\end{array}$ & $H$ & $M$ & $R$ & $\begin{array}{c}H+ \\
100\end{array}$ \\
\hline & & 2 & $U E$ & $H$ & $H$ & $M$ & $U G$ & $U G$ & $H$ & & $R$ & $H+$ \\
\hline
\end{tabular}

Practically no corrosion was found on the specimens to which coatings $C, G$, or $H$ were applied. Rusting was fairly general on pipes beneath the $D, E, F$, and $W$ coatings. These coatings blistered in several of the soils, adhered poorly, and became brittle.

The sheets designated as specimen $B$ became brittle and hardened during exposure. When bent slightly, they cracked in a few instances.

\section{(b) SPECIMENS EXPOSED 2 YEARS}

Nearly all of the nonmetallic coatings buried in 1937 were of the phenol-formaldehyde (bakelite) type, and were applied to pipe $1 \frac{1}{2}$ inches in diameter. The descriptions of the coatings follow:

Coating $L$.-Two coats of a bakelite varnish followed by two coats of another type of bakelite varnish, each coat being baked after spraying. Thickness, 7 mils.

Coating $M_{1}$. - Two coats of a bakelite primer containing zinc chromate followed by two coats of aluminum paste in bakelite varnish. Each coat was sprayed on and allowed to dry overnight. Thickness, 4 mils.

Coating $M_{2}$.-The same as coating $M_{1}$, except that it was applied to $2 \frac{1}{2}$ - by 12 -inch plates instead of to pipe. Thickness, 3 mils. 
Coating N.-A double layer of Bakelite-treated asbestos tape over which was sprayed a Bakelite-aluminum enamel. Thickness, 32 mils.

Coating $P$. - A fabric coated on one side with Koroseal to an over-all thickness of 0.03 inch. The fabric was wrapped spirally on the pipe under tension with the fabric next to the metal and then painted with two coats of Koroseal solution applied hot. Thickness, 33 mils.

Because of the short period of exposure, only a brief summary of the condition of the specimens is given in table 10 .

In the group of coatings exposed for 2 years the Bakelite coating, $L$, consisting of several coats of Bakelite varnish, each coat being baked on, afforded the most complete protection. The air-dried Bakelite coatings blistered somewhat and permitted some rusting, but severe corrosion under these coatings occurred only in cinders.

TABLE 10.-Summary of condition of pipe and coatings exposed 2 years

[Figures in the table refer to the number of test sites]

\begin{tabular}{|c|c|c|c|c|c|}
\hline \multirow{2}{*}{ Coating symbol } & \multicolumn{4}{|c|}{ Pipe } & \multirow{2}{*}{$\begin{array}{l}\text { Coating } \\
\text { blistered }\end{array}$} \\
\hline & Unaffected & Rusted & Roughened & Pitted & \\
\hline $\begin{array}{l}L_{1} \\
M_{1} \\
M_{2} \\
N \\
P\end{array}$ & $\begin{array}{l}5 \\
2 \\
0 \\
5 \\
0\end{array}$ & $\begin{array}{r}29 \\
10 \\
4 \\
5 \\
1\end{array}$ & $\begin{array}{l}0 \\
0 \\
6 \\
3 \\
2\end{array}$ & $\begin{array}{r}11 \\
3 \\
5 \\
2 \\
2\end{array}$ & $\begin{array}{r}0 \\
13 \\
15 \\
0 \\
0\end{array}$ \\
\hline
\end{tabular}

1 Exposed to cinders.

2 Condition possibly due to injury to coating in handling.

3 Poor bond between pipe and coating.

\section{CONCLUSIONS}

The protection afforded by zinc coatings in soils depended on the thickness of the coating and was not appreciably affected by the kind of ferrous material to which the coating was applied. The superior protection which was provided by a 3-ounce zinc coating specially applied, as compared with a commercial coating of the same weight, may indicate that uniformity of coating is important.

Lead coatings applied to iron and steel have not proved adequate for protection underground. Since the potential of lead is cathodic to that of iron, lead cannot protect iron or steel cathodically in the manner that these metals are protected by a zinc coating. As the rate of corrosion of lead is appreciable under many soil conditions, a continuous layer of lead isolating steel from the environment cannot usually be maintained.

Tin-coated copper is susceptible to corrosion in soils which are corrosive to copper. In fact, in some soils the rate of pitting of copper appeared to be accelerated. Under certain conditions one or more tin-copper alloy layers may be cathodic to copper, a condition which would accelerate corrosion.

After exposure to soils for 15 years, two hot-dipped asphalt and coal-tar coatings were found to have failed, as indicated both by pitting of the underlying metal and deterioration of the coating.

Of the group of experimental coatings exposed 7 years, a vitreousenamel coating and two hard-rubber coatings afforded complete protection. 
In the group of coatings exposed 2 years, a Bakelite coating consisting of several coats of Bakelite varnish, each coat being baked on, afforded the most satisfactory protection. The air-dried Bakelite coatings blistered somewhat and permitted some rusting, but severe corrosion under these coatings occurred only in cinders.

The preparation of the specimens, the measurements of corrosion, and the calculation of the results were made under the supervision of Melvin Romanoff. The writer also acknowledges the assistance rendered by David Fickle and Richard F. Thomas in these various operations.

Washington, September 23, 1941. 